\title{
The crustal structure of Egypt and the northern Red Sea region
}

\author{
Ahmed Hosny ${ }^{1}$ and Andrew Nyblade ${ }^{2,3}$ \\ ${ }^{1}$ Seismology Dept., National Research Institute of Astronomy and Geophysics, \\ (NRIAG), 11421 Helwan, Cairo, Egypt \\ ${ }^{2}$ Department of Geosciences, Pennsylvania State University, University Park, PA \\ 16802 \\ ${ }^{3}$ School of Geosciences, The University of the Witwatersrand, Johannesburg, South \\ Africa.
}

\begin{abstract}
P-wave receiver functions from 26 stations in the Egyptian National Seismic Network (ENSN) have been modeled using the H-k stacking method and in a joint inversion method with Rayleigh wave group velocities to investigate crustal structure across Egypt and the northern Red Sea region. The new estimates of crustal structure, when combined with previous results, show that the rifted margins along the Red Sea, Gulf of Suez and Gulf of Aqaba crustal thickness ranges from 25-30 km, the average crustal $\mathrm{Vp} / \mathrm{Vs}$ ratio is 1.77 , and the average crustal shear-wave velocity is $3.6 \mathrm{~km} / \mathrm{s}$. Beneath northern and central Egypt, including the Sinai Peninsula, crustal thickness ranges from 32 to $38 \mathrm{~km}$, the average crustal $\mathrm{Vp} / \mathrm{Vs}$ ratio is 1.79 , and the average crustal shear-wave velocity is $3.5 \mathrm{~km} / \mathrm{sec}$. Beneath southern Egypt, crustal thickness ranges from $35-40 \mathrm{~km}$, the average crustal $\mathrm{Vp} / \mathrm{Vs}$ ratio is 1.76 , and the average crustal shear-wave velocity is $3.7 \mathrm{~km} / \mathrm{s}$. In southern Egypt, the crust is also characterized by a $10-20 \mathrm{~km}$ thick mafic lower crust. These findings indicate that crust along the rifted margins of the northern Red Sea, and Gulfs of Suez and Aqaba have been thinned by about 5 to $10 \mathrm{~km}$. The thick mafic lower crust in southern Egypt can be attributed to suturing during the Neoproterozoic collision of east Gondwana against the Sahara metacraton. Overall, the structure of the crust in Egypt away from the northern Red Sea region is similar to the structure of Precambrian crust in many other parts of Africa.
\end{abstract}


Keywords

Egypt; Crustal structure; Velocity Model

\section{Introduction}

Compared to many parts of the African continent (i.e., eastern and southern Africa), little is known about crustal structure in the northeastern corner of the continent. In this paper, we address the lack of knowledge by modeling crustal structure beneath 26 stations in the Egyptian National Seismic Network (ENSN), and then combining our results with results from previous studies to characterize crustal structure across Egypt and the northern Red Sea region.

Over the past decade, many of the seismic stations in the ENSN have been upgraded with broadband sensors, while others are still equipped with three component short period seismometers. Here we use data from the broadband stations and the highest quality short-period stations to obtain 26 new point estimates of crustal thickness, $\mathrm{Vp} / \mathrm{Vs}$ ratio, and crustal shear-wave velocity. These estimates are obtained by applying the H-k stacking method of Zhu and Kanamori (2000) to teleseismic P-wave receiver functions (PRFs), and by performing a joint inversion of the PRFs with Rayleigh wave group velocities (Juliá et al., 2000, 2003).

While much information on African crustal structure has been obtained from modeling PRFs in the past 20 years (e.g., see Kachingwe et al., 2015 and Tugume et al., 2013 for reviews), and the modeling of PRFs from a small number of broadband stations in the ENSN already has been done by Hosny and Nyblade, (2014), to date there has not been a comprehensive study of crustal structure in Egypt and the northern Red Sea region using seismic data from the ENSN. The results of this study elucidate the amount of crustal thinning beneath the rifted margins along the northern 
Red Sea, and Gulfs of Suez and Aqaba, reveal a region of thick mafic lower crust in southern Egypt, and otherwise show that the Precambrian crust underlying much of Egypt is similar to Precambrian crust in many other parts of Africa. New information on crustal structure provided by this study is also important for seismic hazard studies, particularly for improving seismic event locations in regions of Egypt prone to large earthquakes.

\section{Geologic Background}

Figure 1 shows a simplified geologic map of Egypt. Precambrian basement rocks are exposed primarily in the southern and southeastern parts of the country and within the Sinai Peninsula. Most of the Precambrian basement is part of the northernmost section of the Neoproterozoic Mozambique mobile belt that formed the core of the East African Orogen, as well as the Nubian-Arabian Shield (e.g., Stern and Johnson, 2010 and references therein). However, in southern Egypt, a number of granitic outcrops have been interpreted to be part of the much older so-called Saharan metacraton. The suture between the Neoproterozoic terranes to the east and the metacraton to the west is marked by the Keraf shear zone, which can be traced from northeastern Sudan into southern Egypt (Abdelsalam and Stern, 1996a, b; Abdelsalam

et al., 1998) (Figure 1). The Precambrian basement of the Nubian-Arabian Shield was disrupted along its eastern edge by the formation of the Red Sea in the Late Oligocene and the development of the Dead Sea/Gulf of Aqaba transform fault in the Middle Miocene.

Overlying the Precambrian basement across most of Egypt are Phanerozoic sedimentary rocks. Paleozoic sandstones and shales are found at the base of the sedimentary section, and in many places they are overlain by Mesozoic sandstones, 
Paleogene and Neogene limestones, sandstones, and conglomerates, and unconsolidated Quaternary sediments.

Crustal structure beneath Egypt has been investigated previously in a number of studies. Using seismic refraction, gravity measurements, and tomography, crustal thickness estimates of 24-27 km have been reported along the margins of the northern Red Sea and the Gulf of Suez (Makris et al., 1988; Marzouk, 1988; Ginzberg et al., (1988), Gaulier et al., 1988; Rihm et al., 1991; Salah, 2011; and Abdelwahed et al., 2013). Also, Makris et al., (1988), Rihm et al. (1991), Makris et al. (1988), Guilier et al. (1988), and Abdelwahed et al. (2013) reported crustal thicknesses of 31-38 km inboard of the Red Sea and Gulf of Suez coastlines in northern and central Egypt, while Makris et al. (1988), Dorre et al. (1997) and Abdelwahed et al. (2013) reported crustal thicknesses of 34-40 km in southern Egypt.

Modeling PRFs from data recorded on seven of the ENSN stations, Hosny and Nyblade (2014) reported crustal thicknesses of 35-38 km around Lake Nasser in southern Egypt, and thinner crust $(25-26 \mathrm{~km})$ within $50 \mathrm{~km}$ of the Red Sea coast in southern and central Egypt. Additionally, for a single station in northeastern Egypt (station KEG), Salah (2011) modeled PRFs and obtained a crustal thickness of $33 \mathrm{~km}$.

Estimates of crustal structure from gravity data have been reported by a number of investigators. Tugume et al. (2013) estimated crustal thickness across Africa and Arabia by inverting satellite gravity data. They reported an average crustal thickness of $\sim 30-35 \mathrm{~km}$ for Egypt, with thinner crust $(\sim 25-30 \mathrm{~km})$ near the coastlines. Mechie et al.(2013) also reported Moho depths beneath the Arabian plate and parts of Egypt from satellite gravity data modeling. Along the Red Sea coastline, their models show crustal thicknesses of $\sim 25-30 \mathrm{~km}$, similar to Tugume et al. (2013). 
Estimates of crustal thickness for Egypt from terrestrial gravity data have been reported by Dorre et al. (1997), Saleh et al. (2006), and Tealeb (2003), showing an average crustal thickness beneath Egypt between 32 and $34 \mathrm{~km}$.

\section{Data and Methodology}

\subsection{Data collection}

In 1997, the National Research Institute of Astronomy and Geophysics (NRIAG) established the ENSN. Today, the ENSN consists of 22 stations with broadband seismometers, 10 stations with 3-component short-period seismometers, and 47 stations with single component short-period seismometers. The broadband seismic stations are equipped with $240 \mathrm{~s}$ or $120 \mathrm{~s}$ Trillium sensor, a Trident digitizer, and a GPS (Global Positioning System) clock. Data are recorded at 100 or 200 samples per second. Data from 26 of the ENSN stations, including the 22 broadband stations and 4 of the highest quality three-component short-period stations (stations DK2, MRS, KAT, and BST; Figure 1) have been used in this study (Figure 1). To compute receiver functions, we used data for teleseismic events with magnitudes $\geq$ 5.5 within epicentral distances of $30^{\circ}$ to $90^{\circ}$ recorded between 2008 and 2013 . Figure 2 shows the locations of the events used, and a list of the earthquakes is provided in the supplemental material.

\subsection{Receiver Functions}

Receiver functions are a time series that show the response of Earth's structure beneath a recording station and are commonly used to investigate crustal structure (Langston, 1979). The direct $\mathrm{P}$ wave, the P-to-S conversion from the Moho (Ps), and reverberations between the Moho and the free surface (PpPs and PsPs+PpSs) are the 
main phases observed in the time series. The thickness of the crust and the Poisson's ratio can be determined using the arrival times of the direct and the converted phases (Langston, 1979; Ligorria and Ammon, 1999; Zandt and Ammon, 1995; Zhu and Kanamori, 2000).

To compute the receiver functions, each seismogram was de-trended and tapered, and a $0.05-8 \mathrm{~Hz}$ bandpass filter was applied to remove the low frequency noise. The waveforms were then decimated to 10 samples per second to avoid aliasing, and were cut 10 s before and 80 s after the first P-wave arrival. Next, the horizontal components were rotated to the great circle path to obtain radial and transverse components. The vertical component was then deconvolved from the radial and tangential components using the iterative time-domain deconvolution method (Ligorria and Ammon, 1999). A maximum of 500 iterations were used in the deconvolution method (Ligorria and Ammon, 1999).

Radial and tangential receiver functions were computed for each seismic event using Gaussian width factors of $1.0(0.5 \mathrm{~Hz})$ and $2.5(1.25 \mathrm{~Hz})$. The lower frequencies $(0.5 \mathrm{~Hz})$ result in longer wavelength receiver functions, which are best for observing longer period phases from the lower crust and mantle, while higher frequency receiver functions $(1.25 \mathrm{~Hz})$ can reveal detailed phases from shallow crustal structures (Owens and Zandt, 1985; Ligorria and Ammon, 1999; Julià et al., 2007).

To assess the quality of the receiver functions, a least squares minimization of the difference between the original radial component and the predicted radial component was applied. The predicted radial component was generated by convolving the original vertical component and the radial receiver function. A similarity of $85 \%$ or greater was used to select receiver functions for further analysis. In addition, events that resulted in transverse receiver functions with large amplitudes 
were not considered for further processing, even if they passed the $85 \%$ criterion. Figure 3 illustrates the quality of receiver functions for one station.

\subsection{H-k stacking method}

The H-k stacking method of Zhu and Kanamori (2000) was applied to the receiver functions to estimate the crustal thickness and the $\mathrm{Vp} / \mathrm{Vs}$ ratio beneath each seismic station. This method reduces the ambiguity in Moho depth $(\mathrm{H})$ and $\mathrm{Vp} / \mathrm{Vs}(\kappa)$ estimates by incorporating the later multiple converted phases from the Moho (PpPs and PsPs+PpSs). In this method, the receiver functions are transformed from the timeamplitude domain into the stacking domain through

$$
s(H, k)=\sum_{j=1}^{N} w_{1} r_{j}\left(t_{1}\right)+w_{2} r_{j}\left(t_{2}\right)-w_{3} r_{j}\left(t_{3}\right)
$$

where $t_{i}$ are the travel times of the three main P-to-S converted phases from the Moho (Ps, PpPs, and PsPs+PpSs), $\mathrm{w}_{\mathrm{i}}$ are weights assigned to each phase (sum of wi=1), $\mathrm{r}_{\mathrm{j}}$ is the receiver function amplitude for the $\mathrm{j}$-th receiver function, and $\mathrm{N}$ is the number of receiver functions. $\mathrm{S}(\mathrm{H}, \kappa)$ reaches its maximum when optimal values for $\mathrm{H}$ and $\kappa$ are determined, satisfying a simple layer over a half-space model.

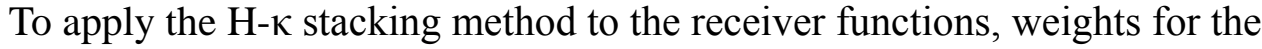
converted phases (Eq. 1) and an average crustal Vp must be selected. For each seismic station, an average crustal P-wave velocity of 6.3 and $6.5 \mathrm{~km} / \mathrm{s}$ were used, which are typical values for Precambrian crust (e.g., Christensen and Mooney, 1995). The first two phases, Ps and PpPs, were more clearly seen in the receiver function waveforms for most stations, so we gave a weight to each of them of 0.4. The PsPs+PpSs 
multiple was not as clear on many of the receiver functions and therefore we downweighted it $\left(\mathrm{w}_{3}=0.2\right)$.

Results from the $\mathrm{H}-\kappa$ stacking method for crustal thickness and $\mathrm{Vp} / \mathrm{Vs}$ ratio are tabulated in Table 1, examples for two stations are illustrated in Figures 4 and 5, and results for the other stations are provided in the supplemental material. The $\mathrm{H}-\kappa$ stacking method was performed on PRFs computed with both 1.0 and 2.5 Gaussian filters for all stations, and similar results were obtained using both filters.

For each seismic station, the formal uncertainties in both $\mathrm{H}$ and $\kappa$ were estimated by bootstrapping the receiver function dataset (Julià and Mejía, 2004) using 200 replications (Efron and Tibshirani, 1991). The formal uncertainties for each station using a mean crustal $\mathrm{Vp}$ of 6.3 and $6.5 \mathrm{~km} / \mathrm{s}$ for the $\mathrm{H}-\kappa$ stacking are given in Table 1 . An overall uncertainty in $\mathrm{H}$ is obtained by combining the formal uncertainty with the range in $\mathrm{H}$ obtained using a crustal $\mathrm{Vp}$ of 6.3 and $6.5 \mathrm{~km} / \mathrm{s}$, and the overall uncertainty in $\kappa$ is similarly obtained. The overall uncertainty in $\mathrm{H}$, at each seismic station is thus $\sim+/-2 \mathrm{~km}$, and the overall uncertainty in $\kappa$ is $\sim+/-0.08$.

Estimates of $\mathrm{H}$ and $\kappa$ were obtained for all seismic stations except the ones without clear multiple converted phases. For the stations without clear Moho reverberations (stations TAMR, NBNS, SWA, MRS, DB2, BST, and FRF), the Moho depth has been computed using the Moho Ps arrival time, taken from a stack of the PRFs, and from the equation from Zandt et al. (1995) for $\mathrm{H}$, an average crustal $\mathrm{Vp}$ of $6.5 \mathrm{~km} / \mathrm{s}$ and a $\mathrm{Vp} / \mathrm{Vs}$ ratio of 1.75 .

\subsection{Joint inversion of the receiver functions and Rayleigh wave group velocities}

Using the method of Juliá et al. (2000, 2003), the shear wave velocity structure of the crust beneath a seismic station can be obtained by jointly inverting receiver 
functions and Rayleigh wave group velocity measurements. This method employs a linearized damped least-squares inversion that incorporates a priori smoothness and influence constraints. A combination of surface wave dispersion curves and receiver functions provides constraints on the shear wave velocity of the propagation medium ultimately improving those provided by either of the datasets modeled separately. This approach helps to prevent over-interpretation of single datasets (Ozalaybey et al., 1997; Juliá et al., 2000, 2003, 2005; Dugda et al., 2007).

For each dataset, the inversion was performed using receiver functions at low and high pass Gaussian filter bandwidths of $1.0(f \leq 0.5 \mathrm{~Hz})$ and of $2.5(\mathrm{f} \leq 1.25 \mathrm{~Hz})$, respectively. For constraining the crust and uppermost mantle, fundamental-mode Rayleigh wave group velocities between periods of 10 and 100 s from Pasyanos and Nyblade (2007) are used. The starting model used in the inversion consists of a $38 \mathrm{~km}$ thick crust with a linear increase in S-wave velocity from 3.0 to $4.0 \mathrm{~km} / \mathrm{s}$, overlying a flattened PREM (Preliminary Reference Earth Model) model for the mantle (Dziewonski and Anderson, 1981). Following the approach of Juliá et al. (2008) for investigating the lateral variability of crustal structure around each seismic station, receiver functions were stacked into four groups by ray parameter, from 0.04 to 0.049 (with average value of 0.045 ); from 0.05 to 0.059 (with average value of 0.055 ); from 0.060 to 0.069 (with average value of 0.065 ); and from 0.070 to 0.079 (with average value of 0.075$)$. For each seismic station, at least three receiver functions from each ray parameter group were used in the stacking.

The velocity model used in the inversion is parameterized with layers of constant velocity. Layer thicknesses are 1 and $2 \mathrm{~km}$ at the top of the model, $2.5 \mathrm{~km}$ thick between 5.5 and $53 \mathrm{~km}$ depth, $5 \mathrm{~km}$ thick between 53 and $260 \mathrm{~km}$ depth, and 10 $\mathrm{km}$ thick below a depth of $260 \mathrm{~km}$. Velocities were fixed to PREM values below a 
depth of $200 \mathrm{~km}$. Poisson's ratio was fixed at 0.25 for crustal layers and at PREM values for mantle layers. During the inversion, an a priori smoothness factor of 0.1 was used for all stations and equal weight was given to the receiver functions and Rayleigh wave group velocities. The results for two stations are illustrated in Figure 6, and the Vs models for all the stations are shown in Figure 7. Results for the remaining stations are provided in the supplemental material.

\section{Results}

Shear wave velocities for typical lower crustal lithologies derived from experimentally determined $\mathrm{Vp} / \mathrm{Vs}$ ratios have shown that the shear wave velocities in the lower crust do not likely exceed $4.3 \mathrm{~km} \mathrm{~s}^{-1}$ and that velocities greater than $4.3 \mathrm{~km}$ $\mathrm{s}^{-1}$ are typical for mantle lithologies (Christensen \& Mooney 1995; Christensen 1996). Therefore, following the approach of Kachingwe et al. (2015) and Tugume et al. (2013), in the joint inversion models the Moho is defined as the depth at which the shear wave velocity exceeds $4.3 \mathrm{~km} \mathrm{~s}^{-1}$ (Figure 7). For most stations there is also a significant increase in velocity or a velocity discontinuity at the depth where the velocity exceeds $4.3 \mathrm{~km} \mathrm{~s}^{-1}$. Additionally, from the models we obtain an average crustal shear wave velocity beneath each seismic station as well as the thickness of the mafic layering in the lower crust. Holbrook et al. (1992), Christensen and Mooney (1995), Rudnick and Fountain (1995), and Rudnick and Gao (2003) reported that common lower crustal mafic lithologies, such as amphibolites, garnet-bearing and garnet-free mafic granulite, and mafic gneiss, have high shear-wave velocities (> 3.9 $\mathrm{km} / \mathrm{s})$ while intermediate-to-felsic lithologies have lower shear-wave velocities $(\leq 3.9$ $\mathrm{km} / \mathrm{s}$ ). Therefore, we define the mafic lower crust as layers in the model with shearwave velocities between $4.0 \mathrm{~km} / \mathrm{s}$ and $4.3 \mathrm{~km} / \mathrm{s}$. 
Results are summarized in Table 1. Based on the locations of the stations, we divided our study area into three geographic regions; (1) the rifted areas along the Red Sea, Gulf of Suez, and Gulf of Aqaba, (2) northern and central Egypt, and (3) southern Egypt. Moho depths beneath stations in region 1 (stations HRG, NADB, MRS, BST, and SHRM) are shallower, ranging from 26-30 km, with an average $\mathrm{Vp} / \mathrm{Vs}$ ratio of 1.77 . The mean crustal shear-wave velocity beneath this region is 3.6 $\mathrm{km} / \mathrm{s}$, and the average thickness of the mafic lower crust is $5 \mathrm{~km}$.

Beneath stations in northern and central Egypt, including the Sinai Peninsula (stations NKL, KOT, NBNS, SLM, SIWA, FRF, TAMR, KAT, and DB2), the Moho depth ranges from $32-38 \mathrm{~km}$, the average $\mathrm{Vp} / \mathrm{Vs}$ is 1.79 , the average crustal shearwave velocity is $3.5 \mathrm{~km} / \mathrm{s}$ and the average mafic lower crustal thickness is $3 \mathrm{~km}$. Beneath stations in southern Egypt (stations NAHD, NMAN, NNAL, MABD, NGRW, NGMR, NWAL, NWKL, DK2, NKUR, and NSKD), the Moho depth ranges from $35-40 \mathrm{~km}$, the average $\mathrm{Vp} / \mathrm{Vs}$ ratio is 1.76 , the average crustal shear-wave velocity is $3.7 \mathrm{~km} / \mathrm{s}$, and the average mafic lower crust thickness is $15 \mathrm{~km}$.

\section{Discussion}

No previous estimates of crustal structure from seismic data have been reported for several parts of Egypt, including the interior of the Sinai Peninsula, central Egypt, and northern Egypt along the Mediterranean coast. Results from this study thus provide new information about crustal structure for many parts of Egypt, and when combined with previously published results, can be used to more fully characterize crustal structure across Egypt and the northern Red Sea region. The ensemble of results of crustal structure across Egypt, the northern Red Sea and the 
Gulfs of Suez and Aqaba, as well as beneath the northern Arabian Peninsula, is shown in Figure 8.

Where crustal structure beneath Egypt has been previously studied (see section 2.0), a comparison of published results with our findings shows good agreement. For example, along the rifted margins of the Red Sea and Gulf of Aqaba, estimates of crustal thickness in a number of studies (e.g. Makris et al., 1988; Marzouk, 1988; Ginzberg et al., 1988; Gaulier et al., 1988; Rihm et al., 1991; Hosny and Nyblade, 2014) range from $\sim 25-30 \mathrm{~km}$. Similarly, estimates of crustal thickness inboard from the coastlines in these studies indicate thicker crust, in the range of $\sim 30-34 \mathrm{~km}$, with the thickest crust found in south-central Egypt around Lake Nasser ( 35-40 km) (Hosny and Nyblade, 2014). The Vp/Vs ratios obtained in this study for these regions are also similar to those reported by Hosny and Nyblade (2014), ranging between 1.7 and 1.8 , on average.

Compared to crustal thickness estimates along the Arabian side of the Gulf of Aqaba and northern Red Sea, our results are similar to results obtained by Thalčic et al. (2006) and Al-Damegh et al. (2005). They report crustal thicknesses from 27 to 32 $\mathrm{km}$ beneath the Arabian rifted margins, and an average $\mathrm{Vp} / \mathrm{Vs}$ ratio of 1.75 . In comparison to crustal structure in the Arabian-Nubian Shield beneath Saudi Arabia, there is also good agreement. The average crustal thickness and Vp/Vs for the Arabian Shield in Saudi Arabia is $37 \mathrm{~km}$ and 1.76, respectively, similar to our results for southern, central and northern Egypt.

The compilation of results shown in Figure 8 indicates that there has been a 5 to $10 \mathrm{~km}$ of crustal thinning along the rifted margins of the northern Red Sea, and Gulfs of Suez and Aqaba. Figure 8 shows a consistent crustal thickness of 25-30 km beneath all of the stations along the rifted margins in Egypt and Saudi Arabia. The 
figure also shows crust that is $35-40 \mathrm{~km}$ thick away from the rifted margins beneath Egypt, the interior of the Sinai Peninsula, and the Arabian Shield of 35-40 km. Thus, the pre-rift crustal thickness beneath all of the rifted margins was likely in the 35-40 $\mathrm{km}$ range, and so $\sim 5$ to $10 \mathrm{~km}$ of crustal thinning must have occurred to create the 25 $30 \mathrm{~km}$ thick crust found beneath the rifted margins.

Compared to crustal structure in similar tectonic settings elsewhere in Africa, our results also show good agreement. Crustal thickness beneath the Cenozoic East African Rift ranges from about 20-35 km (Fuchs et al., 1997 and references therein), overlapping with the range in crustal thickness we observe along the rifted margins of the Red Sea and the Gulf of Aqaba. Kachingwe et al. (2015) published a compilation of crustal structure for Precambrian terrains in the southern African subcontinent, expanding on the previous compilation of Tugume et al. (2013). Kachingwe et al. (2015) reported average crustal thicknesses of between 35 and $42 \mathrm{~km}$, average $\mathrm{Vp} / \mathrm{Vs}$ ratios of 1.7-1.8, and average crustal shear wave velocities of 3.6 to $3.8 \mathrm{~km} / \mathrm{s}$ for five Neoproterozoic terrains. They also reported an average crustal thickness of $37 \mathrm{~km}$, an average $\mathrm{Vp} / \mathrm{Vs}$ ratio of 1.75 , and an average crustal shear wave velocity of $3.6 \mathrm{~km} / \mathrm{s}$ for the Mozambique Belt. As outlined previously, the Precambrian crust beneath most of Egypt is part of the Neoproterozoic Mozambique Belt. The crustal thickness beneath this area of Egypt ranges from $32-40 \mathrm{~km}$, the $\mathrm{Vp} / \mathrm{Vs}$ ratios range from 1.76 to 1.79 , and the average crustal shear-wave velocities range from 3.6 to $3.7 \mathrm{~km} / \mathrm{s}$, in close agreement with the crustal parameters reported by Kachingwe et al. (2015) for the Mozambique Belt.

However, the Vs models for stations in southern Egypt reveal a significant difference in lower crustal structure compared to Mozambique Belt structure elsewhere in Africa. The lower crust beneath stations in the Lake Nasser region is 
characterized by a thick layer of high velocity (> $3.9 \mathrm{~km} / \mathrm{s}$ ) rock, which we interpret as mafic lower crust. The average thickness of the mafic lower crust is $15 \mathrm{~km}$ (Table 1). In contrast, the thickness of the mafic lower crust in other parts of the Mozambique Belt is $2 \mathrm{~km}$, and the mafic lower crust is no thicker than $7 \mathrm{~km}$ on average in many other Neoproterozoic terrain in Africa (Kachingwe et al., 2015).

The region in southern Egypt where we observe the thickened mafic lower crust (around Lake Nasser) is situated along a mapped Precambrian suture zone, the Keraf shear zone, which likely formed during the collision between east Gondwana and the Sahara metcraton during the final assembly of Gondwana in the Neoproterozoic, about 640-560 Ma (Johnson et al., 2011; Stern and Johnson, 2010; Bailo et al., 2003; Abdelsalam and Stern, 1996 a,b; Abdelsalam et al., 1998) (Figure 1). In Precambrian terrains of other ages in southern Africa where similarly thick, mafic lower crust is found, Kachingwe et al. (2015) attributed the mafic layering to suturing during continent-continent collision. Thick mafic crustal layers within Precambrian suture zones is also commonly observed in other continents (e.g., Thomas and Tanner, 1975; Kearey, 1976; Gibb and Thomas, 1976, 1977; Gibb et al., 1983; Mathur, 1974; Black et al., 1979). Consequently, we attribute the thick mafic lower crust in southern part of Egypt to modification of the crust during the collisional event that marked the final assembly of Gondwana in which east Gondwana collided with the Saharan metcraton.

The position of the Keraf suture zone in central and northern Egypt is uncertain, and so the lack of thick mafic crust beneath the stations to the north of the Lake Nasser region could simply result from a lack of station coverage. Or alternatively, the nature of the collisional event during the formation of Gondwana may have been different to the north of the Lake Nasser region. 
As a final discussion point, we note that the velocity models obtained in this study also have value for hazard risk reduction for Egypt. Seismic hazards are significant within parts of Egypt (see Ambraseys, 2005 for reviews of seismicity in Egypt), and well constrained velocity models can be used to improve earthquake locations. To provide regional models useful for seismicity studies, we have averaged the velocity models from the stations in each of the three regions in Table 1. The average models are shown in Figure $7 \mathrm{~d}$ and the velocity models are provided in the supplemental material.

\section{Summary and Conclusions}

To summarize, using seismic data from 26 station in the Egyptian National Seismic Network, estimates of crustal thickness, mean crustal shear-wave velocity, mean crustal $\mathrm{Vp} / \mathrm{Vs}$ ratio, and the thickness of the mafic lower crust have been obtained.. No previous estimates of crustal structure from seismic data have been reported for several parts of Egypt, including the interior of the Sinai Peninsula, central Egypt, and northern Egypt along the Mediterranean coast. Results from this study thus provide new information about crustal structure for those parts of Egypt.

In areas of Egypt where crustal structure has been previously studied, a comparison of published findings with our results shows good agreement. Similarly, our results compare favorably with crustal thickness estimates along the Arabian side of the Gulf of Aqaba and northern Red Sea, and in the Arabian Shield. Compared to crustal structure in similar tectonic settings elsewhere in Africa, our results also show good agreement, except for in southern Egypt, where the thickness of the mafic lower crust is substantially greater than that beneath Neoproterozoic terrains in eastern, southern, and western Africa. We attribute the thickened mafic lower crust to 
modification of the crust that occurred during the collision between east Gondwana and the Sahara metcraton along the Keraf suture zoneduring the final assembly of Gondwana in the Neoproterozoic.

When new results from this study are combined with results from previous studies, it is apparent that the crust is uniformly $35-40 \mathrm{~km}$ thick beneath regions of Egypt, the Sinai Peninsula, and the Arabian Shield away from the rifted margins of the northern Red Sea, and Gulfs of Suez and Aqaba. Thus, the pre-rift crustal thickness beneath the rifted margins was likely in the $35-40 \mathrm{~km}$ range, and so $\sim 5$ to 10 $\mathrm{km}$ of crustal thinning has probably occurred beneath the rifted margins to create the 25-30 km thick crust observed there.

\section{Acknowledgments}

This research work has been funded partially by Science and Technology development Fund in Egypt (STDF) and the National Science Foundation (grant OISE 053006). We thank the two anonymous reviewers for valuable comments.

\section{References}

Abbott, D.H., Mooney, W.D., VanTongeren, J.A. (2013). The character of the Moho and lower crust within Archean cratons and the tectonic implications. Tectonophysics. $609,690-705$.

Abdelsalam, M.G., Stern, R.J., (1996). Sutures and shear zones in the ArabianNubian Shield. Journal of African Earth Sciences 23, 289-310.

Abdelsalam, M.G., Stern, R.J., (1996). Mapping Precambrian structures in the Sahara

Desert with SIR-C/X-SAR radar:the NewProterozoic Keraf Suture, NE Sudan, Journal Geophysical Research, 101 (E10), 23, 63-23, 076. 
Abdelsalam, M.G., Stern, R.J., Copeland, P., Elfaki, E.M., Elhur, B., Ibrahim, F.M., (1998).The Neoproterozoic Keraf suture in NE Sudan: Sinistral transpression along the eastern margin of West Gondwana. Journal of Geology 106, 133-147.

Abdelwahed M.F., El-Khrepy S., and Qaddah A., (2013). Three-dimensional structure of Conrad and Moho discontinuities in Egypt, Journal of African Earth Science, 85, p. 87-102.

Al-Damegh, K., Sandvol, E., and Barazangi, M., (2005). Crustal structure of the Arabian plate: New constraints from the analysis of teleseismic receiver functions: Earth and Planetary Science Letters, v. 231, p. 177-196.

Ambraseys, N. N., C. E Melville, and R. D. Adam (2005). The Seismicity of Egypt, Arabia and the Red Sea: A Historical Review, Cambridge University Press. Ammon, C.J. (1990). The isolation of receiver effects from teleseismic P waveforms. Bulletin of Seismological Society of America.81(6), 2504-2510.

Bailo, T., Schandelmeier, H., Franz, G., Sun, C.-H., Stern, R.J., (2003). Plutonic and metamorphic rocks from the Keraf suture (NE Sudan). A glimpse of Neoproterozoic evolution on the NE margin of W. Gondwana. Precambrian Research 123, 67-80. Black, J.M., Boullier, A.M., Moussine-Pouchkine, A., Bayer. R., Berlad, A.M., Fabre, J., and Lesquer, A., (1979). Evidence for late Precambrian plate tectonics in West Africa, Nature, 287: 223-227.

Christensen, N. I., and W. D. Mooney (1995). Seismic velocity structure and composition of the continental crust: A global view, J. Geophys. Res., 100, 97619788.

Christensen, N. I. (1996). Poisson's ratio and crustal seismology, J. Geophys. Res., 101, 3139-3156. 
Dorre, A.S., Carrara, E., Cella, F., Grimaldi, M., Hady, Y.A., Hassan, H., Rapolla, A., Roberti, N., (1997). Crustal thickness of Egypt determined by gravity data, Journal of African Earth Sciences 25, 425-434.

Dugda, M. T., Nyblade, A. A., J. Julià, (2007). Thin lithosphere beneath 831 the Ethiopian Plateau revealed by a joint inversion of Rayleigh wave group velocity and receiver functions, J. Geophys. Res., 112, B08305, doi: 10.1029/2006JB004918.

Durrheim, R.J. and Mooney, W.D. (1994). Evolution of the Precambrian Lithosphere: Seismological and geochemical constraints. Journal ofGeophysical Research. 99, $15359-77715374$.

Dziewonski, A. and D. L. Anderson (1981). Preliminary reference Earth model, Phys. of Earth and Planet Int., 25,297-356.

Efron, B., and Tibshirani, R. (1991). Statistical data analysis in computer age. Science. 253, 390-395.

Egyption Geological Survey and Mining Authority, (1981). Geologic map of Egypt: EGSMA, Ministry of Industry and Mineral Resources, Cairo, SCALE 1:2,000,000. Fuchs, K., Altherr, R., Muller, B. and Prodehl, C. (Editors) (1997). Structure and Dynamic Processes in the Lithosphere of the Afro-Arabian Rift System,Special Issue, Tectonophysics. 278, 352pp.

Holbrook, W. S., Mooney, W. D. and Christensen, N. I. (1992). The seismic velocity structure of the deep continental crust, in Continental Lower Crust, edited by Fountain D. M., Arculus, R and Kay, R. W., chapter 1, 1-43, Elsevier Amsterdam.

Hosny, A., and Nyblade, A. (2014). Crustal structure in southeastern Egypt: Symmetric thinning of the northern Red Sea rifted margins, , Geology, March 2014, v.42, p. 219-222. 
Johnson , P.R., Andresen A., Collins A.S., Fowler, A.R., Fritz, H., Ghebreab, W., Kusky, T., Stern, R.J., (2011). Late Cryogenian-Ediacaran history of the ArabianNubian Shield: A review of depositional, plutonic, structural, and tectonic events in the closing stages of the northern East African Orogen, Journal of African Earth Sciences 61, 167-232.

Julià, J., Ammon, C. J., Herrmann, R. B., Correig, A.M. (2000). Joint inversion of receiver function and surface wave dispersion observations. Geophysical Journal International. 143, 99-112.

Gaulier, J.M., Le Pichon, X., Lyberis, N., Avedik, F., Geli, L., Moretti, I., Deshamps, A., and Hafez, S., (1988). Seismic study of the crust of the northern Red Sea and Gulf of Suez: Tectonophysics, v. 153, p. 55-88, doi:10.1016/0040 -1951(88)90007-8.

Gibb, R.A. and Thomas, M.D., (1976). Gravity signature of fossile plate boundaries in the Canadian Shield, Nature, 262: 199-200.

Gibb, R.A. and Thomas, M.D., (1977). The Thelon front: a cryptic suture in the Canadian Shield? Tectonophysics, 38: 211-222.

Gibb, R.A. and Thomas, M.D., Laponite, P. and Mukhopadhay, M., (1983).

Geophysics of proposed Proterozoic sutures in Canada. Precambrian Res., 19: 349384.

Julià, J., Ammon, C. J., Herrmann, R. B., (2003). Lithosphere structure of the Arabian Shield from the joint inversion or receiver functions and surface-wave group velocities. Tectonophysics.825 371, 1-21.

Julià, J., and Mejía, J., (2004). Thickness and Vp/Vs ratio variation in the Iberian crust: Geophysical Journal International, v. 156, p. 59-72, doi:10.1111/j.1365246X.2004.02127.x. 
Julià, J., C. J. Ammon, and Nyblade, A A., (2005). Evidence for mafic lower crust in Tanzania, East Africa, from joint inversion of receiver functions and Rayleigh wave dispersion velocities, Geophys. J. Int., 162, 255-569.

Julià, J. (2007). Constraining velocity and density contrasts across the crust- mantle boundary with receiver function amplitudes. Geophysical Journal International. 171, 286-301.

Julià, J., Assumpcao, M. and Rocha, M.P., (2008). Deep crustal structure of the Paran's basin from receiver functions and Rayleigh-wave dispersion: evidence for a fragmented cratonic root, J. Geophys. Res., 113, B08318, doi: 10.1029/2007 JB005374.

Kachingwe M., Nyblade A., and Julià J., (2015). Crustal structure of Precambrian terranes in the southern African subcontinent with implications for secular variation in crustal genesis, Geophys. J. Int. 202 (1): 533-547.

Kearey, P., (1976). A regional structural model of the Labrador Trough, northern Queber, from gravity studies and its relevant to continent-continent collision in the Precambrian, Earth Planet. Sci. Lett., 28: 371-378.

Langston, C.A., (1979). Structure under Mount Rainier, Washington, inferred from teleseismic body waves: J. Geophys. Res., 85, 4749-4762.

Ligorra, J. P. and C. J. Ammon (1999). Iterative deconvolution and receiver function estimation, Bull. Seism. Soc. Am., 89, 1395-1400.

Makris,J.,Allam, A., Moktar, T., Basahel, A., Dehgani,G.A.and Azari, M. (1983). Crustal structure in the northwestern region of the Arabian Shield and its transition to the Red Sea. Bulletin of the Faculty of Science of King Abdulaziz University, 6, 435447. 
Mathur, S.P., (1974). Crustal structure in southwestern Australia from seismic and gravity data. Tectonophysics, 24: 151-182.

Marzouk I (1988). Study of the crustal structure of Egypt deduced from deepseismic and gravity data. Ph D Thesis Hamburg Univ. Hamburg.

Mechie, J., Z. Ben-Avraham, M. Weber, H.-J. Götze, I. Koulakov, A. Mohsen, and M. Stiller (2013). The distribution of Moho depths beneath the Arabian plate and margins, Tectonophysics, 609, 234-249, doi:10.1016/j.tecto.2012.11.015.

Owens, T. J., and G. Zandt (1985). The response of the continental crust- mantle boundary observed on broadband teleseismic receiver functions. Geophysical Research Letters. 12, 705-708.

Ozalaybey, S., M. K. Savage, A. F. Sheehan, J. N. Louie, and J. N. Brune (1997). Shear-wave velocity structure in the northern Basin and Range province from the combined analysis of receiver functions and surface waves, Bulletin of the Seismological Society of America, 87, 183-199.

Passyanous, M. E., and Nyblade, A. A., (2007). A top to bottom lithospheric study of Africa and Arabia, Tectonophysics, 444, 27-44, doi: 10.1016/j.tecto.2007.07.008.

Rihm, R., Makris, J., and Moller, L., (1991). Seismic survey in the northern Red Sea: Asymmetric crustal structure: Tectonophysics, v. 198, p. 279-295, doi:10.1016/00401951(91)90156-M.

Rudnick, R. L. and Fountain, D.M. (1995). Nature and composition of the continental crust the continental crust: A lower crustal perspective. Review ofGeophysics. 33, 267-309.

Rudnick, R.L. and Gao, S. (2003). Composition of the continental crust. Treatise on 902 Geochemistry. 1-64, 3. Elsevier. 
Salah, M.K., (2011). Crustal structure beneath Kottamiya broadband station, northern Egypt from analysis of teleseismic receiver functions. Journal of African Earth Sciences 60, 353-362.

Saleh, S., Jahr, T., Jentzsch, G., Saleh, A., Abou Ashour, N.M.,( 2006). Crustal evaluation of the Northern Red Sea rift and Gulf of Suez, Egypt from geophysical data: 2-dimensional modeling. Journal of African Earth Sciences 45, 257-278. Stern,R.J.,Johnson,P.R.,2010.ContinentallithosphereoftheArabianPlate:ageologic, petrologic, and geophysical synthesis. Earth-Science Reviews 101, 29-67. Tealeb, A., Gharib, A., Hussein, A.,( 2003). Crustal and upper mantle structure beneath

Al-Fayum short-period station from spectral analysis of P-wave amplitude ratios. J. Geophys.NRIAG2 1, 27-49.

Thalčic, H., M. E. Pasyanous, A. J. Rodgers, R. Gök, W. R. Walter, and A. Al-Amri, (2006). A multistep approach for joint modeling of surface wave dispersion and teleseismic receiver functions: implications for lithospheric structure of the Arabian Peninsula, Journal of Geophysical Research, Vol. 111,b11311, doi:10.1029/2005JB004130, 2006

Thomas, M.D. and Tanner, J.G., (1975). Cryptic suture in the extern Grenville province, Nature, 256: 392-394.

Tugume, F., Nyblade, A., Julià, J. van de Meijde, M. (2013). Precambrian crustal structure in Africa and Arabia: Evidence lacking for secular variation. Tectonophysics. $609,250-266$.

Zandt, G. and C. J. Ammon (1995). Continental crust composition constrained by measurements of crustal Poisson's ratio, Nature, 374, 152-155. 
Zhu, L. and Kanamori, H. (2000). Moho depth variation in Southern California from

teleseimic receiver functions, Journal of Geophysical Research, 105, 2969-2980.

\section{Figure captions:}

Figure 1. Generalized geologic map of Egypt, redrawn after Egyptian Geological Survey and Mining Authority (1981). Black triangles show the locations the seismic stations used in this study. Stations DK2, MRS, KAT, and BST are short-period statins and the others are broadband stations.

Figure 2. Map showing the locations of the earthquakes (small solid circles) used in this study centered on the middle of the study region (star). The numbers on the circles give epicentral distance in degrees.

Figure 3. A plot of the radial (left) and tangential (right) receiver functions vs. ray backazimuth for station NAHD computed using a Gaussian filter of 1.0.

Figure 4. H-k stack results for station HRG with weights of w1=0.4 w2=0.4 w3=0.2. On the right are the receiver functions labeled by event back azimuth (top number) and epicentral distance in degrees (bottom number). On the left is the H-k parameter space with the optimal results for $\mathrm{H}$ and $\mathrm{k}$. The contours map out the percentage values of equation (1) given in the text. The optimal results for $\mathrm{H}$ and $\mathrm{k}$ found in the parameter space are summarized along the top with their formal uncertainties.

Figure 5. H-k stack results for station NAHD with weights of w1 $=0.4 \mathrm{w} 2=0.4$ w3 $=0.2$. On the right are the receiver functions labeled by event back azimuth (top number) and epicentral distance in degrees (bottom number). On the left is the H-k parameter space with the optimal results for $\mathrm{H}$ and $\mathrm{k}$. The contours map out the percentage values of equation (1) given in the text. The optimal results for $\mathrm{H}$ and $\mathrm{k}$ found in the parameter space are summarized along the top with their formal uncertainties.

Figure 6. Results from the joint inversion for stations HRG and NAHD. The three panels shown are a) receiver functions, b) Rayleigh wave group velocities, and c) the shear-wave velocity model.

Figure 7. Shear wave velocity models for each station obtained from the joint inversion of PRFs and Rayleigh wave group velocities. (a) Vs models for the stations located in the northern and central Egypt. (b) Vs model for stations located in southern Egypt. (c) Vs model for stations along the rifted margins of the Red Sea and Gulf of Aqaba. (d) The average velocity model for each geographic region; (1) northern and central Egypt, including the Sinai Peninsula, (2) southern Egypt, and (3) 
for the rifted margins of the Red Sea and Gulf of Aqaba. The thin vertical line shows a Vs of $4.0 \mathrm{~km} / \mathrm{s}$ and the vertical dashed line shows a Vs of $4.3 \mathrm{~km} / \mathrm{s}$.

Figure 8. (a) Moho depth in $\mathrm{km}$ and $\mathrm{Vp} / \mathrm{Vs}$ (in small box) for seismic stations in Egypt and the northern Red Sea region. See text for references to stations not part of this study. A-A' and B-B' show the locations of the cross-sections in (b). (b) Cross section showing the crustal thickness variations west-east and southwest - northeast across Egypt, the northern Red Sea, the Gulfs of Suez and Aqaba, and northern Saudi Arabia. Moho depths beneath the Gulf of Suez and Gulf of Aqaba are taken from Gaulier et al. (1988). Cross section B-B' is modified from Hosny and Nyblade (2014). The unlabeled Moho depth estimates in B-B' (small solid squares) are reviewed in Hosny and Nyblade (2014). 


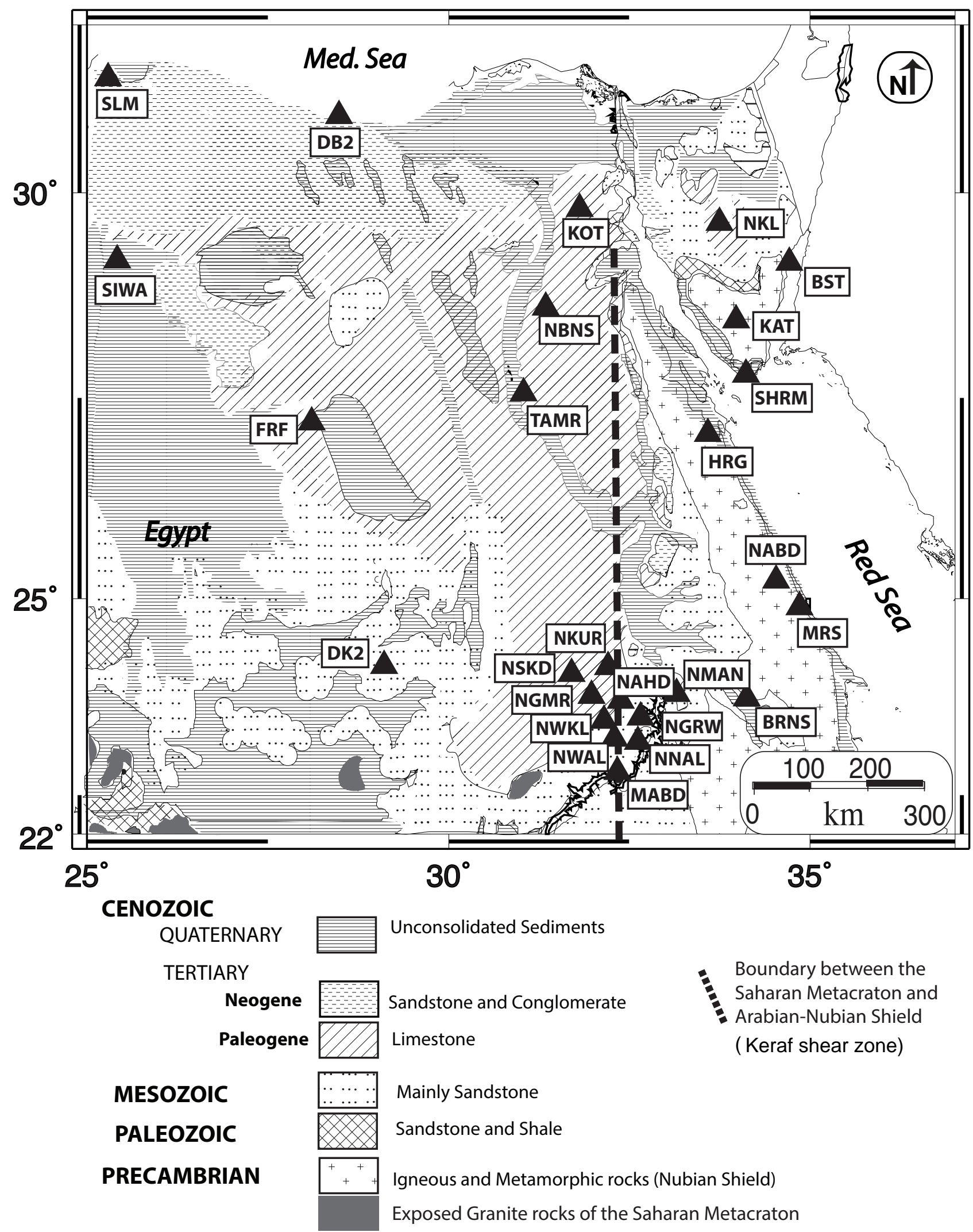

Figure 1. Generalized geologic map of Egypt, redrawn after Egyptian Geological Survey and Mining Authority, EGSM, (1981), Black triangles show the locations the seismic stations used in this study, 24 BB stations and four are SP (DK2, MRS, KAT, and BST) 


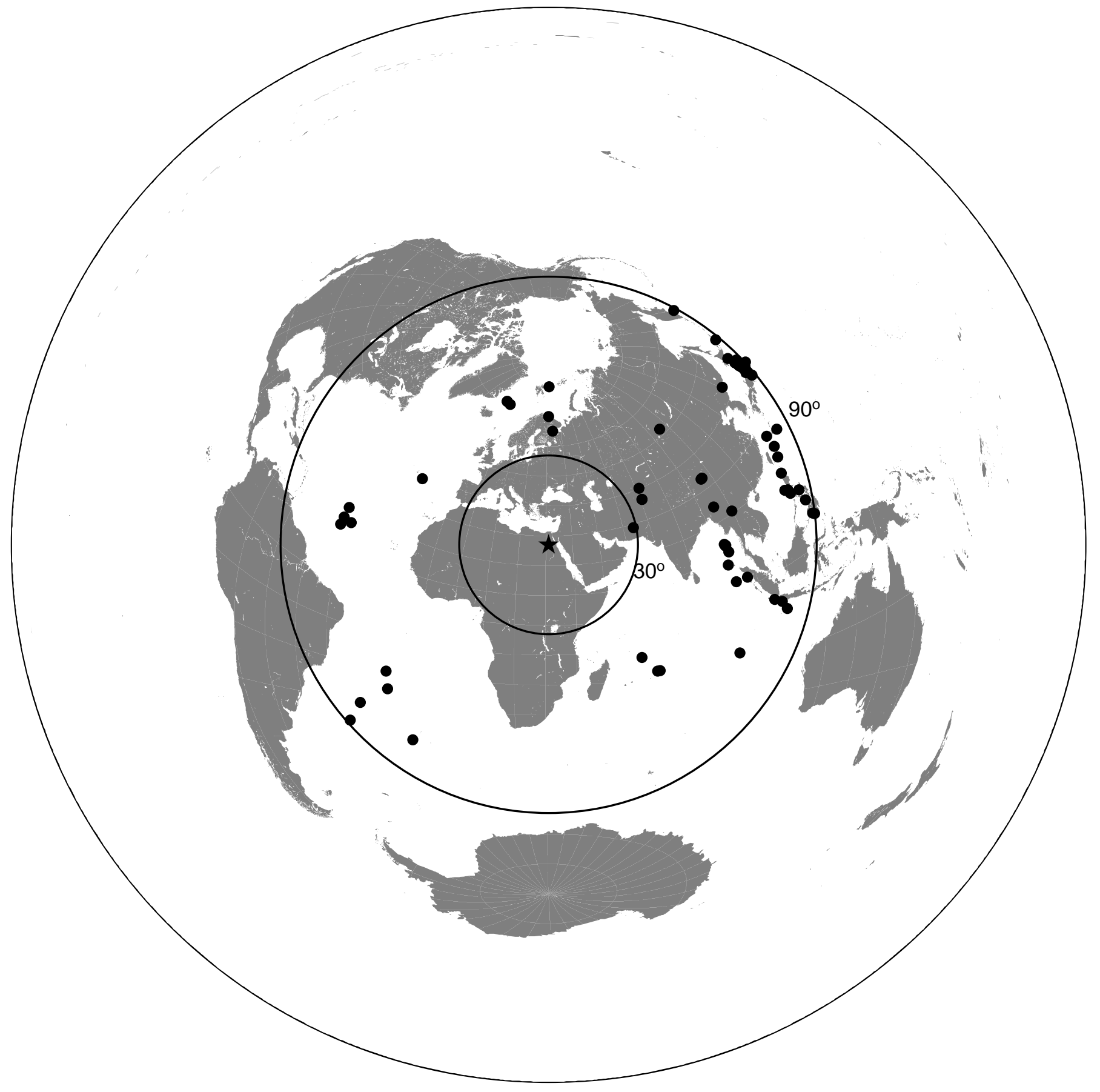

Figure 2.A map showing the locations of the earthquakes (small solid circles) used in this study centered on the middle of the study region (star). The numbers on the circles give epicentral distance in degrees 


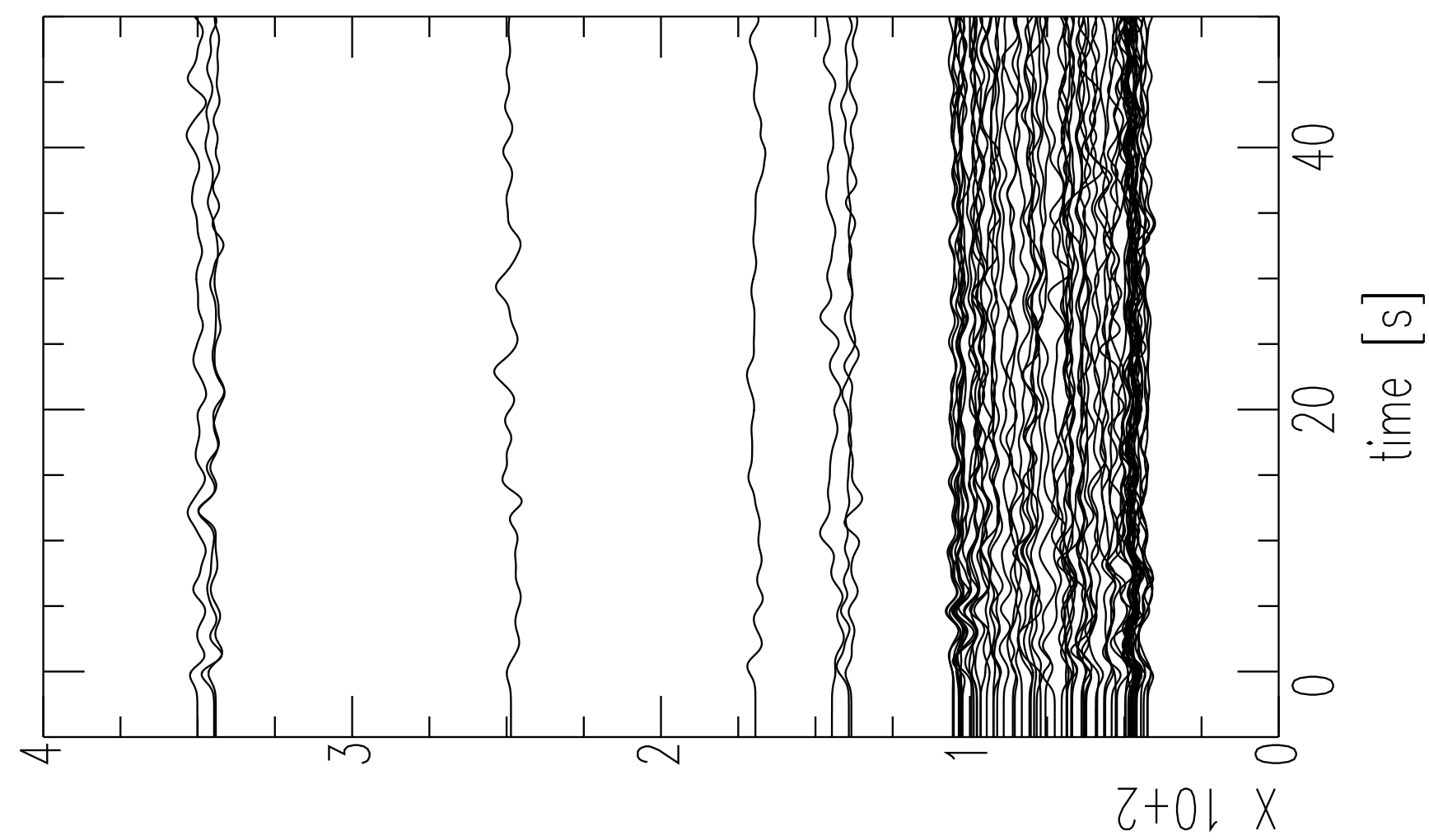

[бәр] 4тпแ!zDyodq

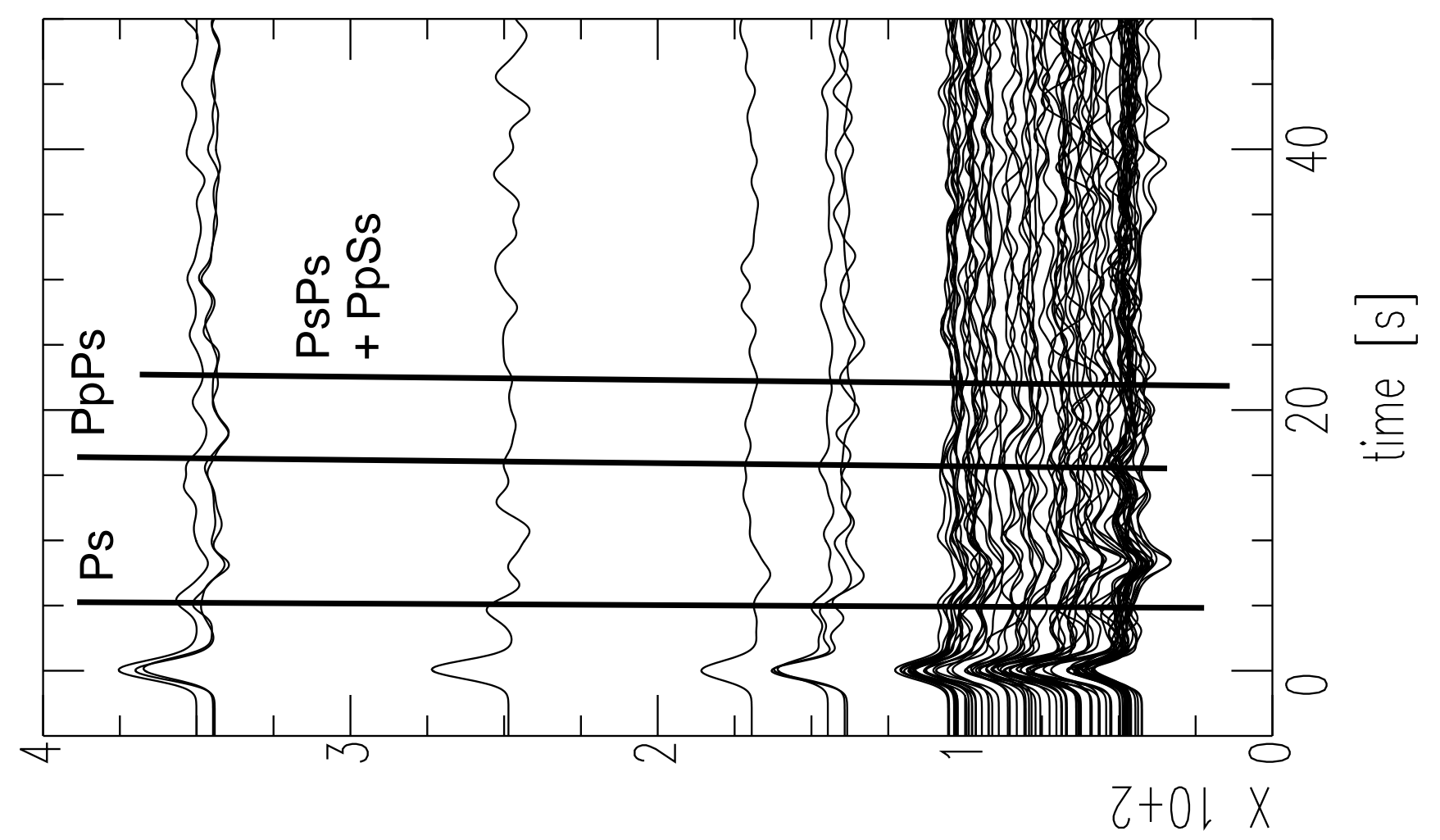

[бәр] 4ұnแ!zDysdq 

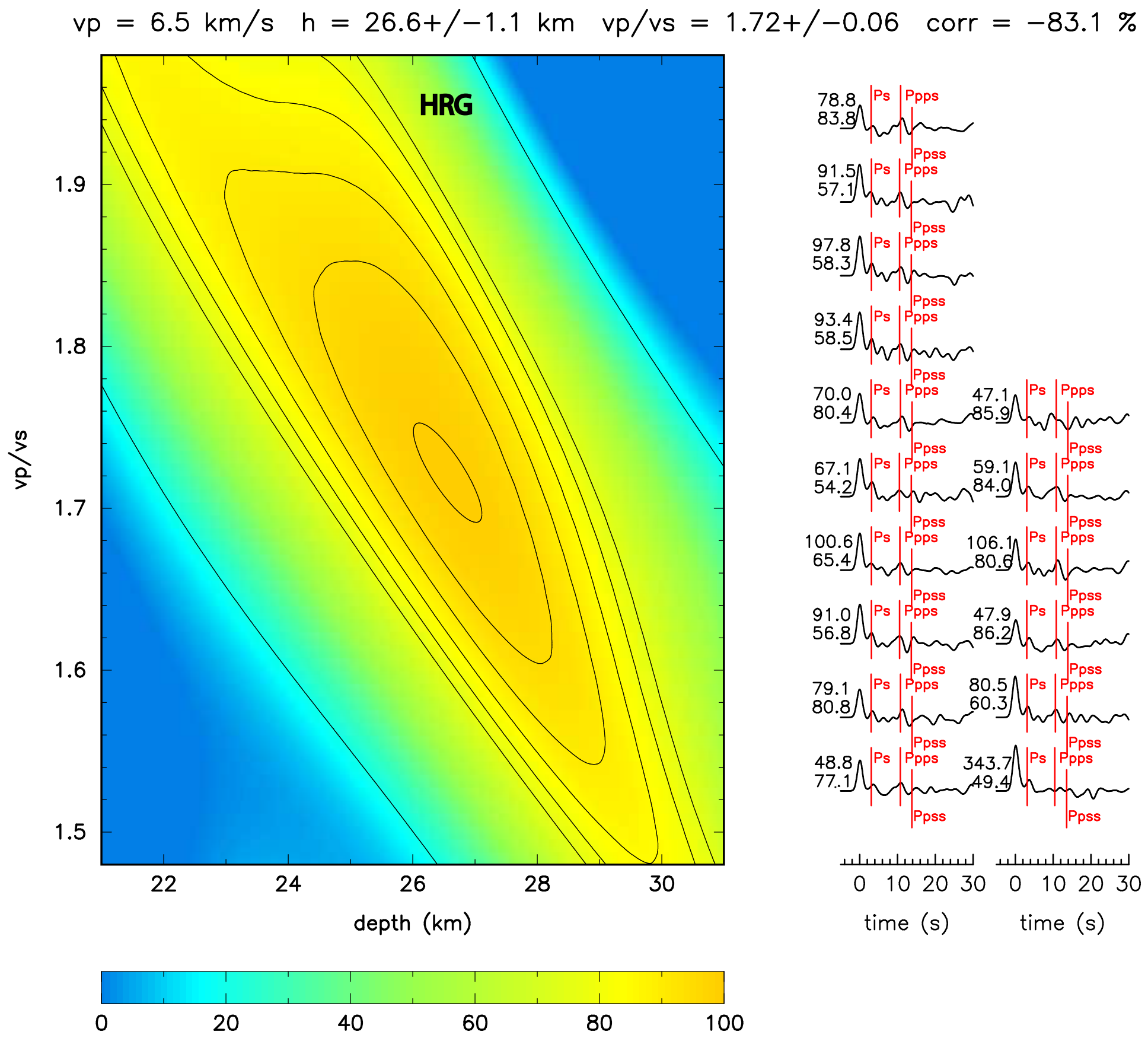

Figure 4. H- $\mathrm{k}$ stack results for station $\mathrm{HRG}$ with weights of $\mathrm{w} \neg \neg 1=0.4 \mathrm{w} 2=0.4 \mathrm{w} 3=0.2$. On the right are the receiver functions labeled by the event's back azimuth (top number) and epicentral distance in degrees (bottom number). On the left is the $\mathrm{H}$ - $\mathrm{k}$ parameter space with the optimal results for $\mathrm{H}$ and $\mathrm{k}$. The contours map out the percentage values of the objective function given in the text. The optimal results for $\mathrm{H}$ and $\mathrm{k}$ found in the parameter space are summarized along the top with their formal uncertainties 


$$
\mathrm{vp}=6.5 \mathrm{~km} / \mathrm{s} \quad \mathrm{h}=39.2+/-1.0 \mathrm{~km} \quad \mathrm{vp} / \mathrm{vs}=1.71+/-0.05 \quad \mathrm{corr}=-96.1 \%
$$

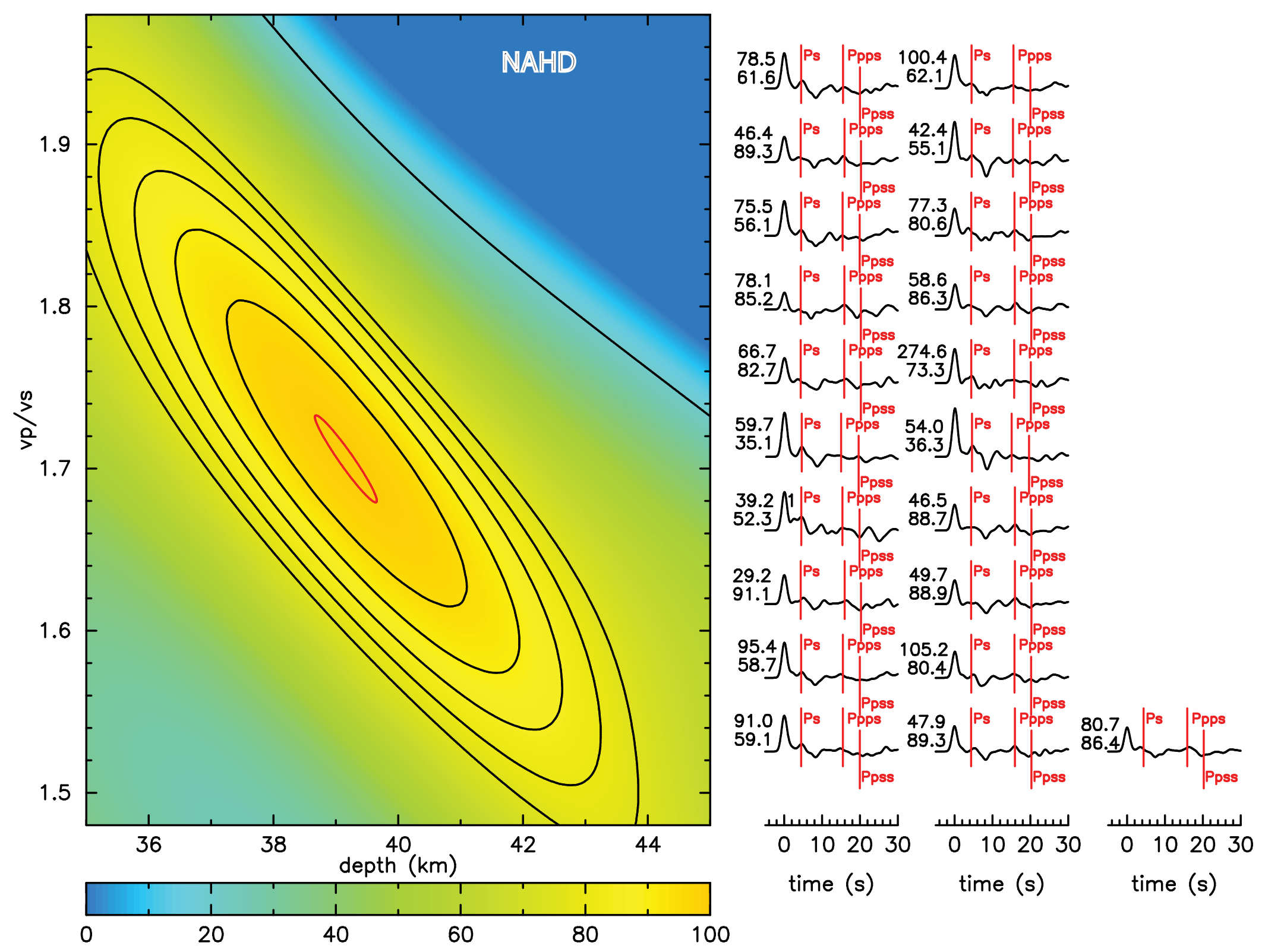

Figure $5 . \mathrm{H}-\mathrm{k}$ stack results for station NAHD with weights of $\mathrm{w} 1=0.4 \mathrm{w} 2=0.4 \mathrm{w} 3=0.2$. On the right are the receiver functions labeled by the event's back azimuth (top number) and epicentral distance in degrees (bottom number). On the left is the $\mathrm{H}-\mathrm{k}$ parameter space with the optimal results for $\mathrm{H}$ and $\mathrm{k}$. The contours map out the percentage values of the objective function given in the text. The optimal results for $\mathrm{H}$ and $\mathrm{k}$ found in the parameter space are summarized along the top with their formal uncertainties 

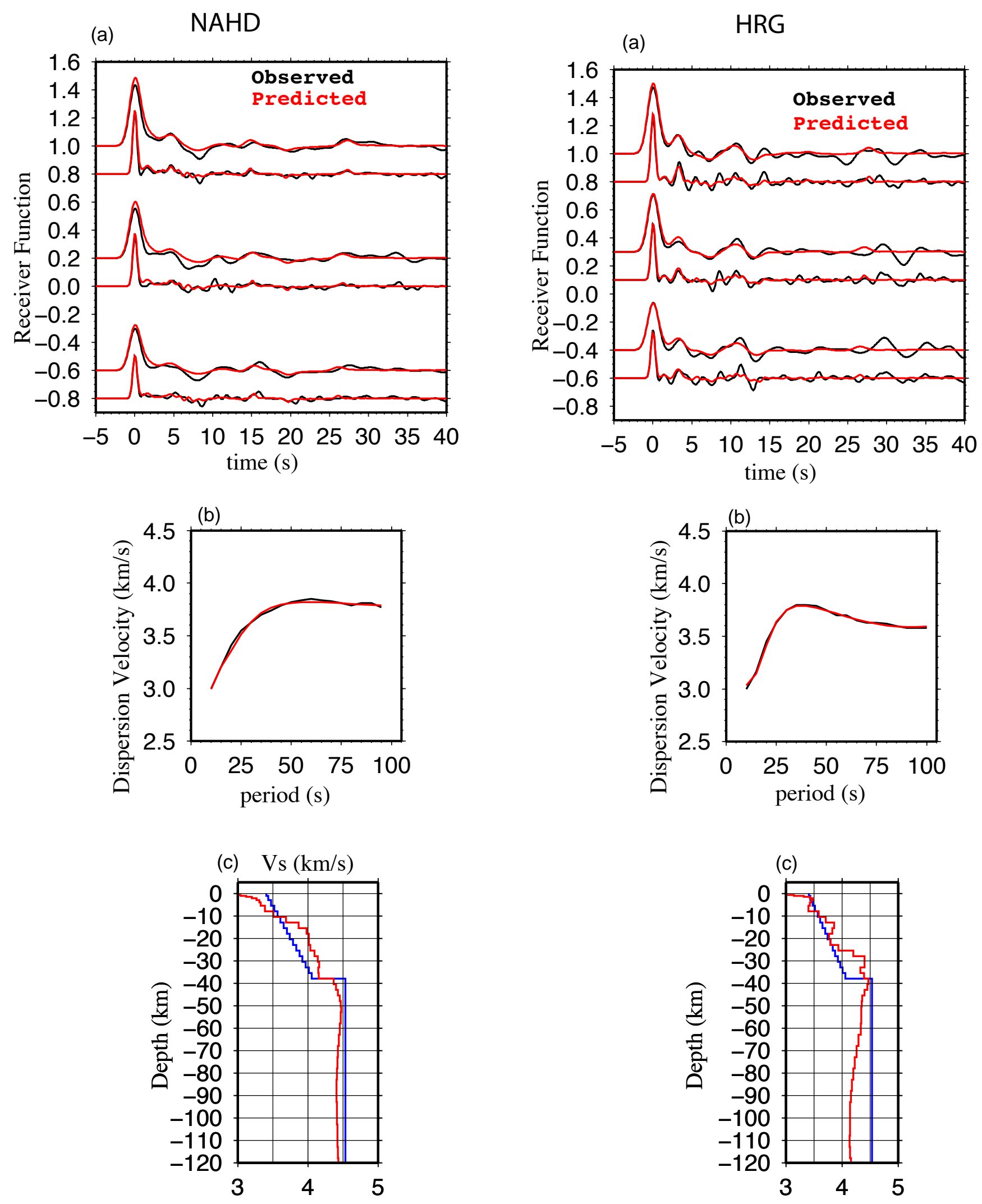

Figure 6. Results from the joint inversion for the stations HRG and NAHD. The three panels shown are a) receiver functions, b) Rayleigh wave group velocities, and c) the shear-wave velocity model. 

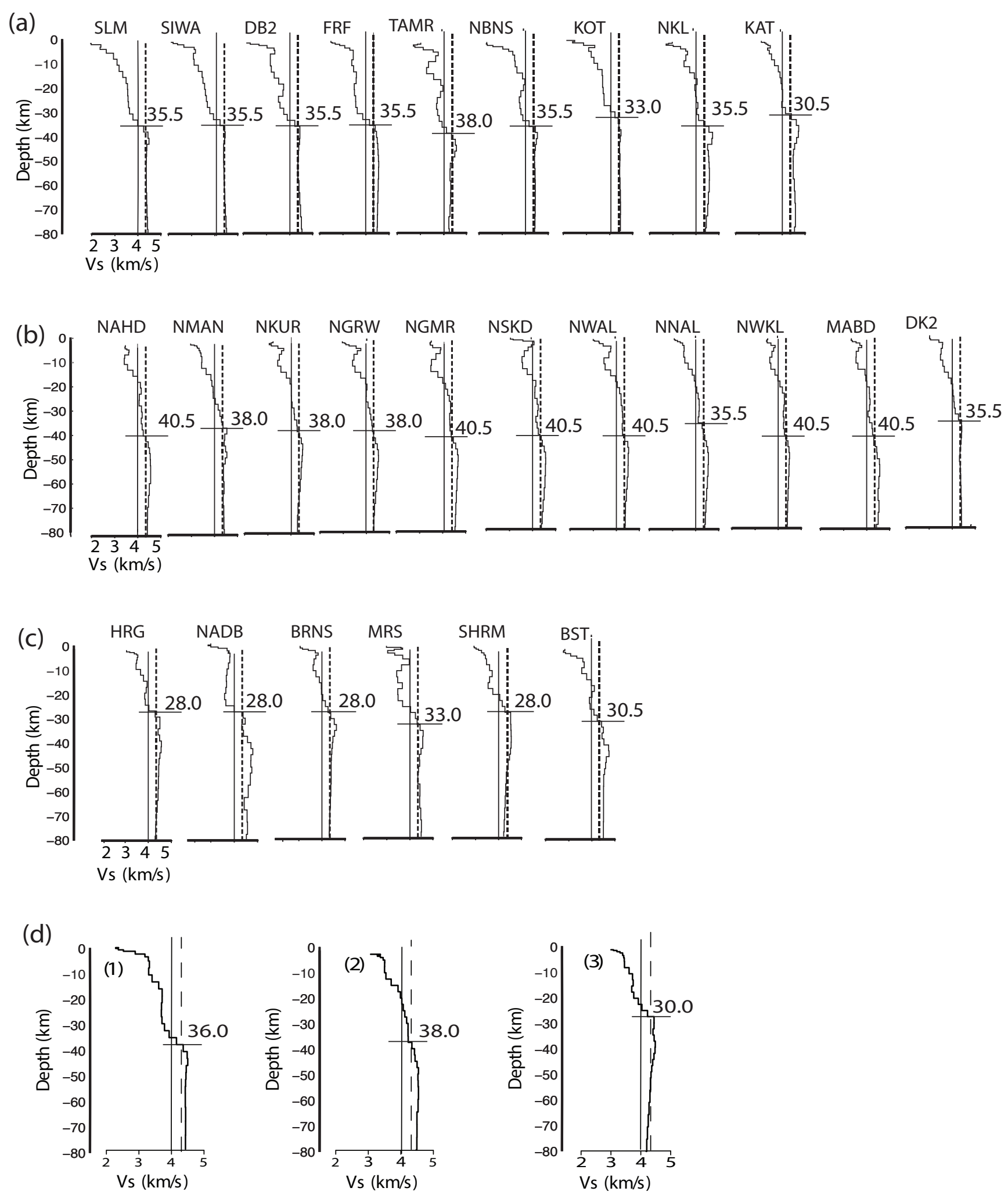

Figure 7. Shear wave velocity modelsfor each station obtained from the joint inversion of PRFs and Rayleigh wave group velocities. (a) Vs models for the stations located in the northern and central Egypt. (b) Vs model for stations located in southern Egypt.(c) Vs model for stations in the rift margins along the Red Sea, Gulf of Suez and Gulf of Aqaba. (d) The average velocity model for each geographic region;(1) northern and central Egypt, (2) southern Egypt, and(3) for the riftedmargins. The thin vertical line shows Vs of $4.0 \mathrm{~km} / \mathrm{s}$ and the vertical dashed line is a $4.3 \mathrm{~km} / \mathrm{s}$. 
(a)
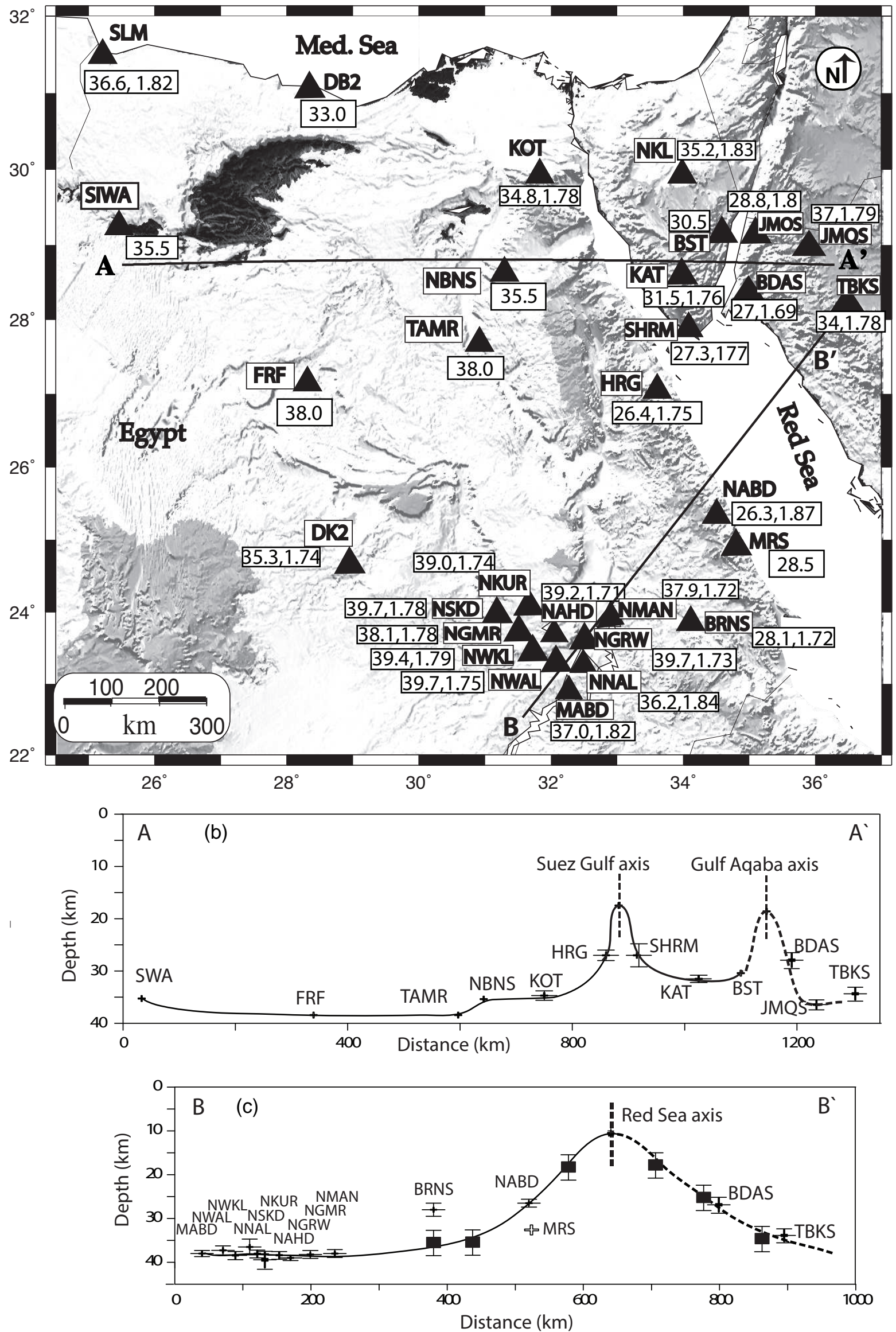

Figure 8.(a ) Moho depth beneath each seismic station used in the current study. Beneath each station, the values of the Moho depth and Vp/Vs ratio are written in the small boxes. A-A' and B-B' show the locations of the cross-sections in (b). (b) Cross section showing the crustal thickness variations west-east and southwest - northeast across Egypt, the northern Red Sea, the Gulfs of Suez and Aqaba, and northern Saudi Arabia. The Moho depth beneath the Gulf of Suez and Gulf of Aqaba is taken from the seismic profiling study of Gaulier et al., 1988. Cross section $\mathrm{B}=\mathrm{B}$ ' is modified from Hosny and Nyblade (2014), with unlabeled Moho depth estimates (small solid squares) are reviewed in that paper. 
Table 1. Crustal structure results for the stations used in this study.

\begin{tabular}{|c|c|c|c|c|c|c|c|c|c|c|c|c|c|}
\hline $\begin{array}{l}\text { Geographic } \\
\text { region }\end{array}$ & $\begin{array}{c}\text { Station } \\
\text { name }\end{array}$ & $\begin{array}{c}\text { Lat } \\
\text { (deg) }\end{array}$ & $\begin{array}{c}\text { Lon } \\
\text { (deg) }\end{array}$ & $\begin{array}{l}\text { Elev. } \\
(\mathbf{m})\end{array}$ & $\begin{array}{l}\text { No of } \\
\text { events }\end{array}$ & $\begin{array}{c}\text { Depth (1) } \\
\text { km }\end{array}$ & $\begin{array}{c}\text { Depth (2) } \\
\text { km }\end{array}$ & $\begin{array}{l}\text { Depth } \\
\text { (3) km }\end{array}$ & $\begin{array}{c}\text { Depth } \\
\text { (4) } \\
\text { km }\end{array}$ & Ratio (1) & Ratio (2) & $\begin{array}{l}\text { Mafic } \\
\text { lower } \\
\text { crust } \\
\text { (km) }\end{array}$ & $\begin{array}{c}\text { Avg } \\
\text { Vs } \\
(\mathbf{k m} / \mathbf{s})\end{array}$ \\
\hline \multirow{5}{*}{$\begin{array}{c}\text { Rifted } \\
\text { areas along } \\
\text { the Red } \\
\text { Sea and } \\
\text { Aqaba } \\
\text { Gulf }\end{array}$} & NADB & 25.3405 & 34.5021 & 298 & 23 & $25.4 \pm 0.8$ & $26.3 \pm 0.9$ & 29.0 & 28.0 & $1.88 \pm 0.05$ & $1.87 \pm 0.05$ & 0.0 & 3.6 \\
\hline & BRNS & 23.8559 & 34.1143 & 332 & 13 & $27.2 \pm 1.7$ & $28.1 \pm 1.5$ & 28.0 & 28.0 & $1.72 \pm 0.05$ & $1.72 \pm 0.05$ & 7.5 & 3.7 \\
\hline & MRS* & 25.0131 & 34.8386 & 215 & 15 & ---- & ----- & 32.5 & 33.0 & ---- & ----- & 5.0 & 3.6 \\
\hline & SHRM & 27.8925 & 34.1322 & 100 & 8 & $26.3 \pm 2.2$ & $27.3 \pm 2.2$ & 27.0 & 28.0 & $1.77 \pm 0.05$ & $1.77 \pm 0.05$ & 7.5 & 3.6 \\
\hline & Average & & & & & $26.0 \pm 1.4+$ & $27.0 \pm 1.3+$ & 28.5 & 29.0 & 1.77 & 1.77 & 4.5 & 3.6 \\
\hline \multirow{6}{*}{$\begin{array}{l}\text { North and } \\
\text { central } \\
\text { Egypt and } \\
\text { Sinai } \\
\text { Peninsula }\end{array}$} & NKL & 29.9293 & 33.9804 & 455 & 19 & $34.0 \pm 0.5$ & $35.2 \pm 0.6$ & 35.5 & 35.5 & $1.84 \pm 0.02$ & $1.83 \pm 0.03$ & 7.5 & 3.7 \\
\hline & KOT & 29.9275 & 31.8291 & 507 & 14 & $33.6 \pm 0.9$ & $34.8 \pm 0.9$ & 35.0 & 35.5 & $1.79 \pm 0.04$ & $1.78 \pm 0.04$ & 2.5 & 3.3 \\
\hline & KAT* & 28.5229 & 33.9927 & 1746 & 17 & $30.5 \pm 1.4$ & $31.5 \pm 1.6$ & 32.9 & 30.0 & $1.77 \pm 0.06$ & $1.76 \pm 0.06$ & 2.5 & 3.6 \\
\hline & NBNS & 28.6226 & 31.2945 & 305 & 17 & --- & --- & 35.5 & 35.5 & --- & --- & 2.5 & 3.2 \\
\hline & DB2 & 31.0470 & 28.5038 & 25 & 20 & ---- & --- & 33.0 & 33.0 & ---- & ---- & 0.0 & 3.4 \\
\hline & Average & & & & & $34.0 \pm 1.0+$ & $34.5 \pm 1.2+$ & 35.9 & 35.0 & 1.80 & 1.79 & 2.5 & 3.5 \\
\hline
\end{tabular}


Table 1. Continue

\begin{tabular}{|c|c|c|c|c|c|c|c|c|c|c|c|c|c|}
\hline $\begin{array}{l}\text { Geographic } \\
\text { region }\end{array}$ & $\begin{array}{c}\text { Station } \\
\text { name }\end{array}$ & $\begin{array}{c}\text { Lat } \\
\text { (deg) }\end{array}$ & $\begin{array}{c}\text { Lon } \\
\text { (deg) }\end{array}$ & $\begin{array}{l}\text { Elev. } \\
\text { (m) }\end{array}$ & $\begin{array}{c}\text { No } \\
\text { of } \\
\text { event }\end{array}$ & $\begin{array}{c}\text { Depth (1) } \\
\text { km }\end{array}$ & $\begin{array}{c}\text { Depth (2) } \\
\text { km }\end{array}$ & $\begin{array}{c}\text { Depth } \\
\text { (3) } \\
\text { km }\end{array}$ & $\begin{array}{c}\text { Depth } \\
\text { (4) } \\
\text { km }\end{array}$ & Ratio (1) & Ratio (2) & $\begin{array}{l}\text { Mafic } \\
\text { lower } \\
\text { crust } \\
(\mathbf{k m})\end{array}$ & $\begin{array}{c}\text { Avg } \\
\text { Vs } \\
(\mathbf{k m} / \mathbf{s})\end{array}$ \\
\hline \multirow{12}{*}{$\begin{array}{c}\text { Southern } \\
\text { Egypt }\end{array}$} & NAHD & 23.8022 & 32.7780 & 100 & 21 & $37.9 \pm 1.1$ & $39.2 \pm 1.0$ & 38.5 & 38.0 & $1.70 \pm 0.07$ & $1.71 \pm 0.05$ & 15.0 & 3.7 \\
\hline & NMAN & 23.9169 & 33.0749 & 100 & 23 & $35.7 \pm 0.9$ & $37.9 \pm 0.9$ & 37.0 & 38.0 & $1.72 \pm 0.04$ & $1.72 \pm 0.04$ & 12.5 & 3.7 \\
\hline & NNAL & 23.2931 & 32.6647 & 100 & 12 & $34.7 \pm 1.9$ & $36.2 \pm 1.8$ & 39.0 & 38.0 & $1.85 \pm 0.07$ & $1.84 \pm 0.06$ & 12.5 & 3.7 \\
\hline & MABD & 22.9226 & 32.3258 & 280 & 12 & $35.7 \pm 0.8$ & $37.0 \pm 0.7$ & 40.0 & 40.5 & $1.85 \pm 0.04$ & $1.82 \pm 0.03$ & 12.5 & 3.7 \\
\hline & NWAL & 23.3829 & 32.5779 & 224 & 15 & $38.3 \pm 1.2$ & $39.7 \pm 1.2$ & 41.8 & 40.5 & $1.76 \pm 0.05$ & $1.75 \pm 0.05$ & 12.5 & 3.7 \\
\hline & NWKL & 23.4130 & 32.4488 & 232 & 15 & $38.0 \pm 0.7$ & $39.4 \pm 0.9$ & 41.6 & 40.5 & $1.80 \pm 0.03$ & $1.79 \pm 0.03$ & 17.0 & 3.8 \\
\hline & NGRW & 23.6684 & 32.7911 & 194 & 29 & $38.3 \pm 0.5$ & $39.7 \pm 0.6$ & 39.6 & 40.5 & $1.73 \pm 0.03$ & $1.73 \pm 0.03$ & 17.0 & 3.7 \\
\hline & NGMR & 23.5217 & 32.4074 & 237 & 22 & $36.9 \pm 0.8$ & $38.1 \pm 0.9$ & 39.6 & 40.5 & $1.79 \pm 0.04$ & $1.78 \pm 0.05$ & 20.0 & 3.8 \\
\hline & NSKD & 28.9893 & 34.6397 & 090 & 17 & $38.4 \pm 2.5$ & $39.7 \pm 2.5$ & 40.8 & 40.5 & $1.79 \pm 0.07$ & $1.78 \pm 0.07$ & 20.0 & 3.7 \\
\hline & NKUR & 24.0040 & 32.6510 & 198 & 24 & $37.6 \pm 0.7$ & $39.0 \pm 0.7$ & 37.5 & 38.0 & $1.74 \pm 0.04$ & $1.74 \pm 0.04$ & 15.0 & 3.7 \\
\hline & DK2* & 24.3195 & 28.9546 & 380 & 13 & $34.1 \pm 2.1$ & $35.3 \pm 2.3$ & 36.0 & 35.5 & $1.75 \pm 0.06$ & $1.74 \pm 0.06$ & 10.0 & 3.7 \\
\hline & Average & & & & & $36.9 \pm 1.1+$ & $38.2 \pm 1.2+$ & 39.2 & 39.1 & 1.77 & 1.76 & 14.9 & 3.7 \\
\hline
\end{tabular}

Depth (1): Crustal thickness from H-k stacking using average $\mathrm{Vp}=6.3 \mathrm{~km} / \mathrm{sec}$

Depth (2): Crustal thickness from H-k stacking using average $\mathrm{Vp}=6.5 \mathrm{~km} / \mathrm{sec}$

Depth (3): Crustal thickness from moho Ps.

Depth (4): Crustal thickness from joint inversion of receiver functions and surface wave dispersion.

Ratio (1), (2): $\mathrm{Vp} / \mathrm{V}$ s ratio form $\mathrm{H}-\mathrm{k}$ stacking using $\mathrm{Vp}=6.3$ and $\mathrm{Vp}=6.5 \mathrm{~km} / \mathrm{sec}$, respectively.

+ uncertainty shown is the standard deviation of the mean

* denotes short-period stations 